
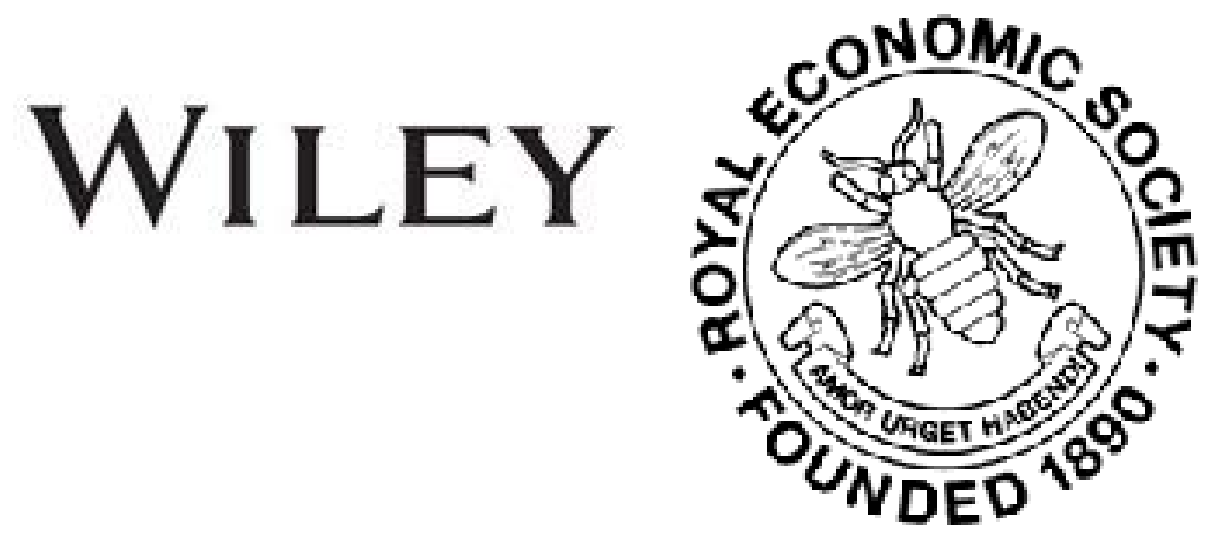

A Note on Mr. Salter's "Allied Shipping Control" Author(s): Percy E. Bates

Source: The Economic Journal, Vol. 31, No. 123 (Sep., 1921), pp. 412-414

Published by: Wiley on behalf of the Royal Economic Society

Stable URL: http://www.jstor.org/stable/2223480

Accessed: 27-06-2016 05:20 UTC

Your use of the JSTOR archive indicates your acceptance of the Terms \& Conditions of Use, available at

http://about.jstor.org/terms

JSTOR is a not-for-profit service that helps scholars, researchers, and students discover, use, and build upon a wide range of content in a trusted digital archive. We use information technology and tools to increase productivity and facilitate new forms of scholarship. For more information about JSTOR, please contact support@jstor.org.

Wiley, Royal Economic Society are collaborating with JSTOR to digitize, preserve and extend access to The Economic Journal 


\section{A Note on Mr. Salter's "Allied Shipping Control" 1}

Mr. SALTER is far too modest : he was no mere passing observer of the events and facts he describes so ably. Rather was he an active working force representing at every moment the most up-to-date phase of the Government's policy as it altered and progressed from time to time. Any one who was at all closely connected with the work at the time will recognise the accurate skill with which the picture is presented. Every struggle of conflicting policies, every force which contributed to the policy finally agreed-all are mentioned, all are there to be discovered by the careful reader. As an accurate record of the facts and events described it is almost impossible that the book will be surpassed.

The book, however, is a great deal more than a record of facts : it constitutes, perhaps unwittingly, a most able defence of Government policy. Unwittingly because neither the author of the book nor the authors of the Government policy appear to realise that the policy needs defence.

It is a truism to say that half this country's population is absolutely dependent on the continuance of its foreign trade. The growth of this trade produced this population, its decline will destroy or remove it. At no stage during the growth of the organisation of Controls was there apparent any regard for this elementary truth. On the contrary, Order after Order, Control after Control were imposed upon British commerce, with no other object than to meet some immediate need, some political outcry, some sudden appeal from Allies or Dominions, or even to gain some political advantage.

To use a phrase which should be recognised by Mr. Salter, it was government by competitive panic. In the last analysis the motives are all reducible to a single one, fear. It was this same motive, fear, which rendered of little effect the attempts at Restriction of Imports and the work of the earlier Committees, such as Lord Curzon's Shipping Control Committee and the Tonnage Priority Committee.

The effect on British commerce has been disastrous. At first it was simply hampered, as it were, incidentally by the forcible rupture of its contracts. Next it was in part destroyed, either as an incident to alleged necessity of supply or because rising

1 Allied Shipping Control : an Experiment in International Administration. By J. A. Salter. (Published by the Clarendon Press on behalf of the Carnegie Endowment for International Peace.) 
prices were politically inconvenient. Finally in parts it was debauched by being taught to make money through Government Control. As seen since the Armistice, the damage to the enterprise and morale of British commerce has been incalculable; the result has been the unemployment doles and will be emigration. These are heavy prices to pay for Control, and can be justified only by the clearest necessity.

The necessity may have been present-almost certainly it was, quite certainly it was growing - but a system which has produced such results, even under the spur of necessity, requires rather an apology than to be held up as an achievement to be admired and as an example for the future. The Government and the author are here at one: both exhibit, or have exhibited, to be admired diagrams of organisation embracing a very large part of British commercial activity.

It would almost appear as if the Government at one time had been consciously working for the complete nationalisation of all commerce, dishonest though it would have been to attempt this under cover of a great war. Probably, however, such a charge would have no foundation. At the same time the Government is only cleared of such a charge at the expense of admitting that it was influenced by competitive panic.

Fortunately for British commerce, and equally fortunately for the population dependent on that commerce, the machinery of Control, British and Allied, never was operated at full power. Fortunately, too, the levers operating Allied Control remained largely in the hands of British Ministries. This occurred chiefly through Allied default, actual or technical, under the various agreements. Had not the Armistice intervened in November 1918, had the war lasted another year, the process of controlling British commerce might well have gone too far to be reversed, and the country might have emerged from the war with the delicate fabric of British commerce irretrievably ruined, and with the inevitable prospect of State monopoly trading.

As it was, the post-Armistice Tonnage Agreement with France on January 22, 1919 (Document 16), postponed the release of British commerce by at least six months, and thus gravely hampered its convalescence.

That there are those who wish to see this country regulated under some form of State Socialism, or even Communism, is well known. It is a curious reflection that the realisation of their desires was prevented only by the termination of hostilities in November 1918. If in 1919 there had been such an office as that

No. 123.-VoL. XXXI. G G 
of the Arch-Controller, British commerce would have most fittingly addressed it in these words, which a Colonel Sexby once wrote to Oliver Cromwell :-

"To your Highness justly belongs the honour of dying for the people; and it cannot choose but be unspeakable consolation to you in the last moments of your life to consider with how much benefit to the world you are like to leave it."

The whole of the remarkable dedication of Colonel Sexby's pamphlet would indeed serve as a complete expression of the attitude of British commerce to the war system of Controls. Such a system may be endured as a necessity; it can never be admired as an example.

Percy E. Bates

\section{OBITUARY}

\section{Arnold JACob Cohen Stuart}

The name of Cohen Stuart is associated with a peculiar variety of the principle which forms the criterion of equity in the distribution of fiscal burdens. Whereas J. S. Mill taught that justice is realised when each tax-payer incurs an equal sacrifice, Cohen Stuart interpreted the dictum as meaning that the sacrifice of each should not be equal absolutely, but should bear the same ratio to the total satisfaction which each individual derives from his income. This doctrine is recommended to some by its leading to a higher rate of progression than the simple equality of sacrifice. To others the conception of a ratio between two amounts of the subjective quantity sacrifice presents difficulty. It is hazardous enough to affirm that the sacrifice felt by one person is greater or less than what is felt by another. Have we faculties capable of measuring the ratio between the pain of privation which a person suffers from an assigned loss of income and the total quantum of satisfaction which he derives from income, and comparing this ratio with the corresponding ratio for another person? A virtual affirmative to this question seems to be given by the high authorities who have accepted the principle of Cohen Stuart. Thus Professor Seligman unhesitatingly accepts the principle as the proper interpretation of Mill's precept. The adhesion of Lord Courtney was equally unequivocal. The authority of 